\title{
Chemostimulating effect of mixture and separate evaporation of manganese (IV) oxide compositions with lead (II) oxide and vanadium (V) oxide on GaAs thermal oxidation
}

\author{
I. Ya. Mittova, V. F. Kostryukov \\ Voronezh State University, Universitetskaya pl.1, Voronezh, 394893 Russia \\ imittova@mail.ru,vc@chem.vsu.ru
}

PACS 81.05.Ea

DOI 10.17586/2220-8054-2015-6-3-424-434

The effects of variable compositions of manganese (IV) oxide - lead (II) oxide and manganese (IV) oxide vanadium (V) oxide on the GaAs thermal oxidation process have been studied. The spatial separation of the oxides in $\mathrm{MnO}_{2}+\mathrm{PbO}$ and $\mathrm{MnO}_{2}+\mathrm{V}_{2} \mathrm{O}_{5}$ binary compositions activating the thermal oxidation of GaAs has made it possible to locate the interactions between these oxides that are responsible for the non-linear effects observed in their coaction. Solid-phase interactions enhance the chemostimulating activities of both oxides (a positive nonlinear effect takes place). Gas-phase interactions cause a marked negative deviation from the additive chemical stimulation effect.

Keywords: semiconductors, gallium arsenide, thin films, thermal oxidation, nonlinear effects.

Received: 13 February 2015

Revised: 19 February 2015

\section{Introduction}

The study of the GaAs thermal oxidation process stimulated by the p-block oxide compositions has revealed the nonlinear effects for various compositions of chemostimulators on the oxide film thickness on the semiconductor surface $[1,2]$. These effects result from additional feedback channels between the chemostimulators, which influence the kinetic blocks of conjugations between various stages of the GaAs oxidation process.

Prior studies [3-5] have demonstrated that in some systems $\left(\mathrm{Sb}_{2} \mathrm{O}_{3}+\mathrm{Bi}_{2} \mathrm{O}_{3}, \mathrm{Sb}_{2} \mathrm{O}_{3}+\right.$ $\mathrm{PbO}, \mathrm{PbO}+\mathrm{Bi}_{2} \mathrm{O}_{3}$ ), such feedback channels are localized with comparable impacts in solid and gas phases. It is, thus, of great interest to examine the revealed dependencies using $\mathrm{d}$ block oxides together with p-block oxide and with any other d-block oxide as well. Manganese is taken as a model element, as its oxidation degrees vary greatly. As it is practically impossible to use the higher oxide $\mathrm{Mn}_{2} \mathrm{O}_{7}$ for the experiment due to its extremely fast decomposition, the study is based on compositions of $\mathrm{MnO}_{2}$ with p-block oxides $(\mathrm{PbO})$ and d-block oxides $\left(\mathrm{V}_{2} \mathrm{O}_{5}\right)$. The individual chemostimulating effects of these oxides have already been studied $[6,7]$.

Thus, the aim of this work is to study the process of gallium arsenide thermal oxidation under the coaction of manganese (IV) oxide - lead (II) oxide, and manganese (IV) oxide - vanadium (V) oxide compositions, and to determine the nature and localization of the nonlinear effects of various compositions of chemostimulators on the oxide film thickness. 


\section{Experimental}

The oxide films were grown on polished single-crystal (111) GaAs wafers (AGChTs-1, gallium face). To determine the gallium face and the arsenic face, the substrate had been chemically milled in $49 \% \mathrm{HF}$ for 20 min. Powdered $\mathrm{MnO}_{2}$ (AR grade, GOST 4470-79), $\mathrm{PbO}$ (AR grade, GOST 9199-68), and $\mathrm{V}_{2} \mathrm{O}_{5}$ (AR grade, TS CM-4566-55) compositions with 20 mole \% steps were used as chemostimulators. The oxygen flow into the reactor was a constant $30 \mathrm{~L} / \mathrm{h}$.

The GaAs oxidation was carried out in a quartz reactor in a horizontal resistor furnace with automated temperature regulation (BPRT-1, with accuracy of $\pm 2^{\circ} \mathrm{C}$ ). The chemostimulator compositions came out of the quartz container and were introduced through the gas phase under conditions isothermal with respect to the substrate being oxidized. The distance from the oxides surface to the working side of the substrate was $10 \mathrm{~cm}$. The sample size was a constant $0.3000 \mathrm{~g}$. The oxidation was carried out at 530 and $560^{\circ} \mathrm{C}$ using the final oxidation method (from 10 to 60) with 10-minute intervals. Using a temperature of $530^{\circ} \mathrm{C}$ allowed comparison of the obtained data with previous results, while $560^{\circ} \mathrm{C}$ was the maximum temperature used to determine the temperature effects on the process. The thicknesses of the oxide films were measured using an LEF-3M ellipsometer with an accuracy of $\pm 1 \mathrm{~nm}$.

To identify the processes and reactions occurring during the chemostimulator binary composition-activated GaAs thermal oxidation, the following methods were used: X-ray powder diffraction ( EMPYREAN), IR spectroscopy (Infralyum FT-02, UR-10), X-ray fluorescence analysis (VRA-30, Carl Zeiss Yena), electron probe X-ray microanalysis (EPXMA, CamScan), and high-temperature mass spectrometry (MS-1301).

\section{Results and discussion}

The dependencies of the oxide films thickness on the chemostimulator compositions $\left(\mathrm{MnO}_{2}+\mathrm{PbO}\right.$ and $\left.\mathrm{MnO}_{2}+\mathrm{V}_{2} \mathrm{O}_{5}\right)$ at both temperatures are presented in Fig.1. The figure shows marked nonlinear effects present in both cases: the actual oxide film thickness is different from the additive value, which is highly dependent upon the temperature, especially for compositions with vanadium oxide.

Dependencies of the oxide films' relative integrated thickness [1] on the composition are shown in Fig.2. The GaAs thermal oxidation activated by $\mathrm{MnO}_{2}+\mathrm{PbO}$ compositions show overall negative deviation from additivity. Both at $530^{\circ} \mathrm{C}$ and $560^{\circ} \mathrm{C}$ the deviation increases with the longer oxidation times. Similar results were obtained when activating the GaAs thermal oxidation with p-block chemostimulator compositions [2]. When a higher temperature is used, however, the results are completely different: the negative deviation from additivity decreases with time, which becomes clear at latter stages of the process.

When GaAs thermal oxidation is activated by $\mathrm{MnO}_{2}+\mathrm{V}_{2} \mathrm{O}_{5}$ at $530^{\circ} \mathrm{C}$ for a short period of time, a variable sign deviation from additivity appears with the overall insignificant change in $\mathrm{d}^{R}$. With time, the variable sign deviation becomes an increasingly negative deviation in all compositions with a minimum of $60 \%$ for vanadium oxide (time interval $60 \mathrm{~min}$ ). At $560^{\circ} \mathrm{C}$ the results are completely different. The variable sign deviation is present regardless of the process duration, and the positive deviation from additivity also increases with time. At the same time, however, the negative deviation also increases (with minimum of $80 \%$ for $\mathrm{V}_{2} \mathrm{O}_{5}$ ). 
Table 1 shows the chemostimulator compositions' X-ray powder diffraction data (presented as interplanar distance) [8]. The chemostimulator compositions studied had been annealed under an oxygen atmosphere at $560^{\circ} \mathrm{C}$, for $30 \mathrm{~min}$. Table 1 shows, that the vanadium oxide system contained vanadium and manganese oxides. In the $80 \% \mathrm{MnO}_{2}+20 \% \mathrm{~V}_{2} \mathrm{O}_{5}$ composition, $\mathrm{Mn}_{2} \mathrm{O}_{3}$ appeared as well as $\mathrm{MnO}_{2}$; in the $20 \% \mathrm{MnO}_{2}+80 \% \mathrm{~V}_{2} \mathrm{O}_{5}$ composition $-\mathrm{MnO}_{2}$ and $\mathrm{Mn}_{3} \mathrm{O}_{4}$ were present. Thus, the lower reduction of manganese (IV) after its partial conversion enhances the transit activeness of the chemostimulator and results in positive deviation from additivity (Fig.2).

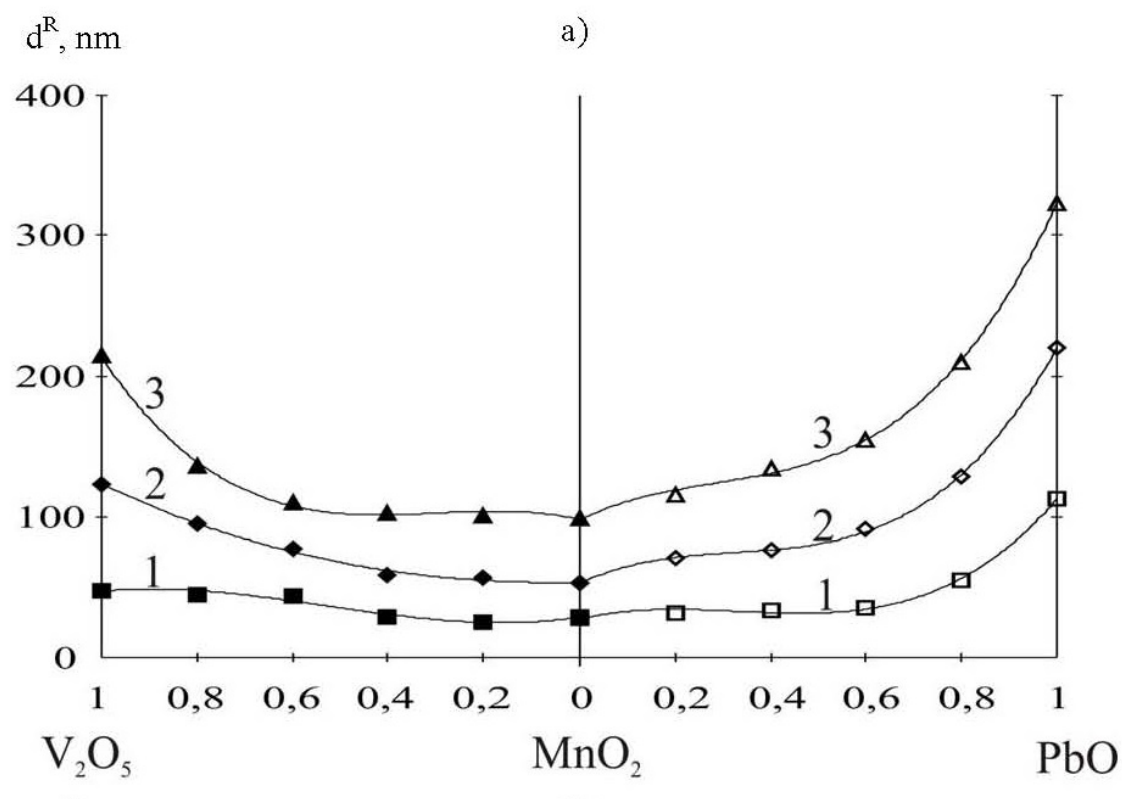

$\mathrm{d}^{\mathrm{R}}, \mathrm{nm} \quad$ b)

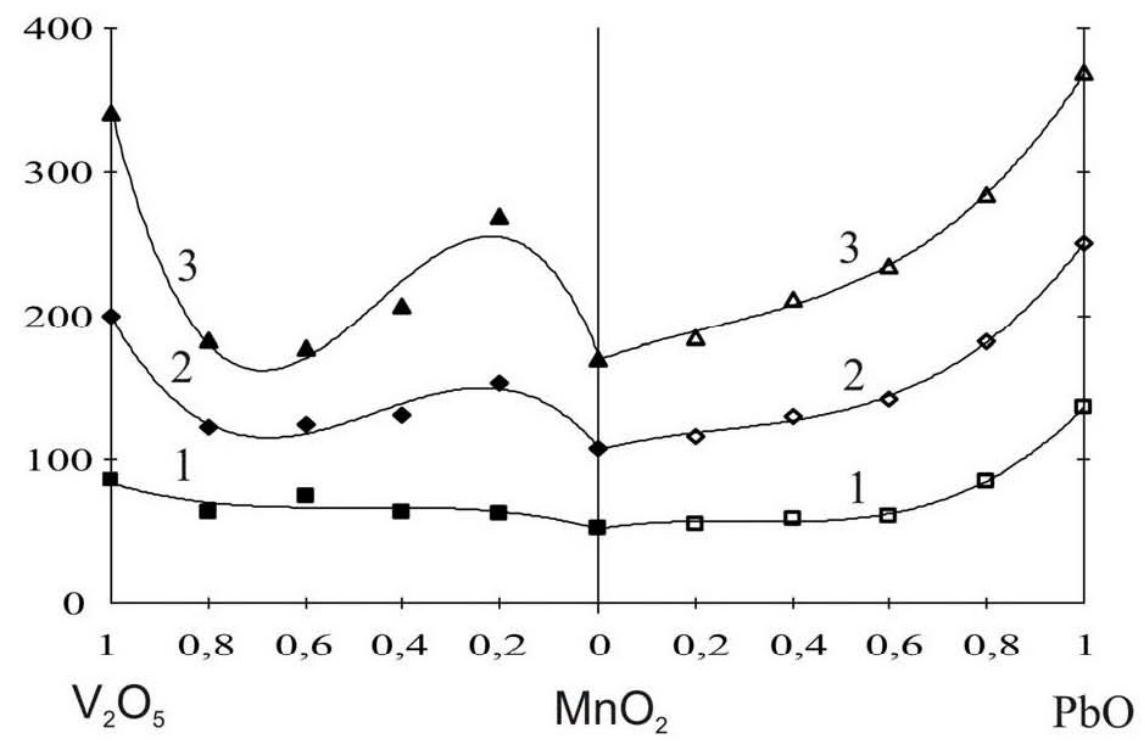

Fig. 1. Concentration dependence of the oxide film thickness on GaAs surface at $530^{\circ} \mathrm{C}$ (a) and at $560^{\circ} \mathrm{C}$ (b) over time intervals: $1-10$ min., $2-30 \mathrm{~min}$., $3-60 \mathrm{~min}$

All the powdered compositions of the lead oxide system contained $\mathrm{PbO}, \mathrm{Pb}_{3} \mathrm{O}_{4}, \mathrm{PbO}_{2}$, $\mathrm{MnO}_{2}, \mathrm{Mn}_{3} \mathrm{O}_{4}$. Manganese and lead did not act together (similarly to the system described 


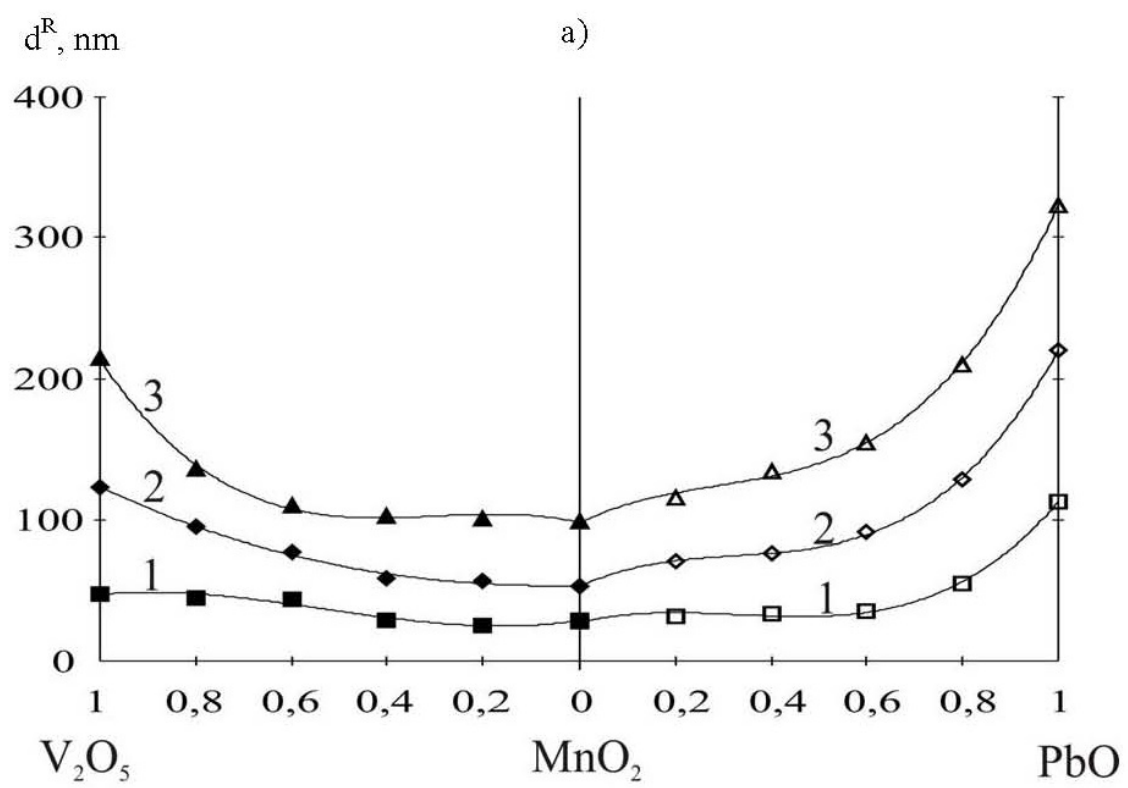

$$
\mathrm{d}^{\mathrm{R}}, \mathrm{nm} \quad \text { b) }
$$

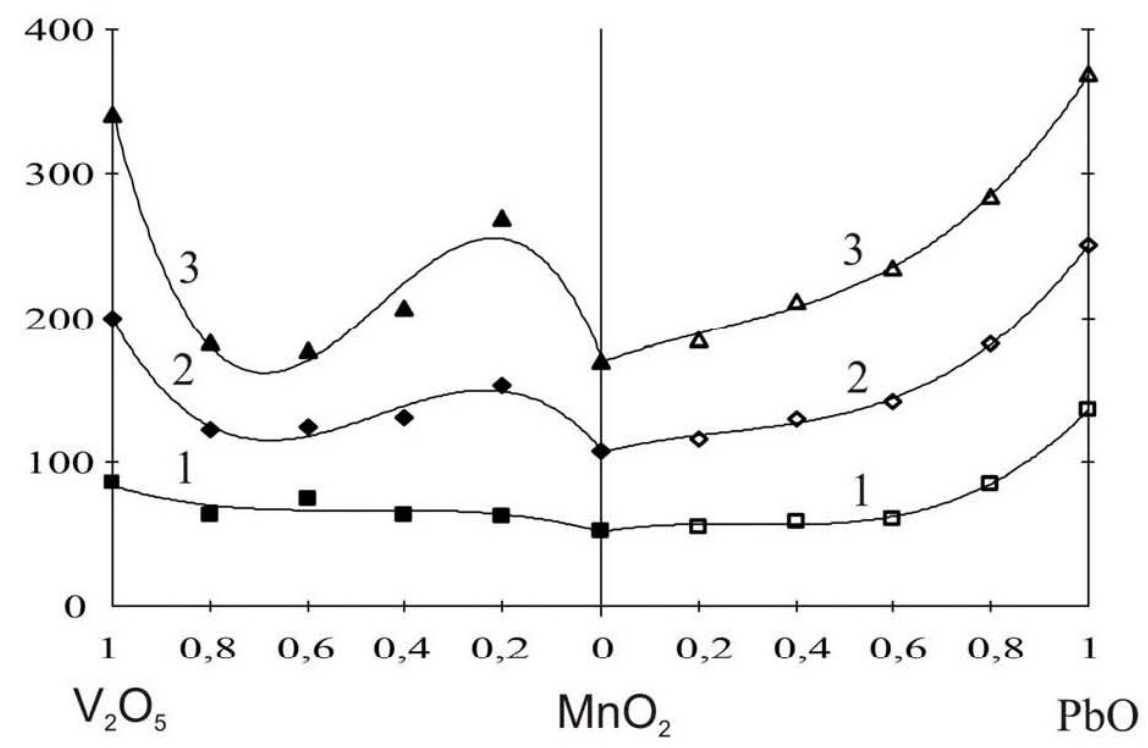

FiG. 2. Relative integrated thickness of the films grown presented as a dependency of chemostimulator composition elements at $530^{\circ} \mathrm{C}$ (a) and at $560^{\circ} \mathrm{C}(\mathrm{b})$ over time intervals 1 - 10 min., $2-30$ min., $3-60$ min

above), but the radiography showed spikes of high intensity that we did not manage to identify. The system showed the same patterns: $\mathrm{MnO}_{2}$ transforms into $\mathrm{Mn}_{3} \mathrm{O}_{4}$ better than in $\mathrm{V}_{2} \mathrm{O}_{5}$ system (due to the additional lead oxide oxidation), which results in overall negative deviation from additivity. Thus, manganese (IV) oxide and lead (II) oxide used together, as well as manganese (IV) oxide and vanadium (V) oxide, affect each other while still being in the container. This results in mixed phases (for $\mathrm{MnO}_{2}+\mathrm{V}_{2} \mathrm{O}_{5}$ ), and in conversion of the initial chemostimulators into compositions with different oxidation degrees (for $\mathrm{MnO}_{2}+\mathrm{PbO}$ ), which changes the evaporation rate and can lead to a joint nonlinear effect for the GaAs thermal oxidation. 
TABLE 1. Interplanar distance $\left(\mathrm{d}_{h k l},\right)$ defined by the X-ray powder diffraction method for chemostimulator compositions $\left(\mathrm{MnO}_{2}+\mathrm{V}_{2} \mathrm{O}_{5}\right)$ and $\left(\mathrm{MnO}_{2}+\mathrm{PbO}\right)$

\begin{tabular}{|c|c|c|}
\hline \multirow{2}{*}{ Phases revealed } & \multicolumn{2}{|c|}{$\mathbf{M n O}_{2}+\mathbf{V}_{2} \mathbf{O}_{5}$} \\
\cline { 2 - 3 } & $20 \mathrm{MnO}_{2}$ & $80 \mathrm{MnO}_{2}$ \\
\hline $\mathrm{V}_{2} \mathrm{O}_{5}$ & $4.374,4.077$ & $4.374,4.077$ \\
\hline $\mathrm{MnO}_{2}$ & $1.445,1.570$ & $3.058,2.186$ \\
\hline $\mathrm{Mn}_{2} \mathrm{O}_{3}$ & - & $1.848,1.361$ \\
\hline $\mathrm{Mn}_{3} \mathrm{O}_{4}$ & $2.495,1.499$ & - \\
\hline \multirow{2}{*}{ Phases revealed } & $20 \mathrm{MnO}_{2}$ & $40 \mathrm{MnO}_{2}$ \\
\cline { 2 - 3 } & $5,906,1,722$ & 1.918 \\
\hline $\mathrm{PbO}^{2}$ & 1.639 & 2.876 \\
\hline $\mathrm{Mn}_{3} \mathrm{O}_{4}$ & 1.208 & 1.514 \\
\hline $\mathrm{PbO}_{2}$ & 3.069 & 1.993 \\
\hline $\mathrm{MnO}_{2}$ & 2.006 & 1.488 \\
\hline $\mathrm{Mn}_{3} \mathrm{O}_{4}$ & 5.574 & $5.754,3.401$ \\
\hline Intermediate phase & & \\
\hline
\end{tabular}

The X-ray powder diffraction and IR spectroscopy methods are complementary. The first method allows us to determine the presence of a certain element in the film, while the second is used to obtain information about the state of the element. The samples used for analysis were determined according to the extreme points of the dependencies of relative integrated oxide film thickness of on the chemostimulator composition at the maximal temperature and duration, i.e. $40 \% \mathrm{MnO}_{2}-60 \% \mathrm{~V}_{2} \mathrm{O}_{5}, 80 \% \mathrm{MnO}_{2}-20 \% \mathrm{~V}_{2} \mathrm{O}_{5}, 40 \% \mathrm{MnO}_{2}-$ $60 \% \mathrm{PbO}$ at $560^{\circ} \mathrm{C}$ for $60 \mathrm{~min}$. X-ray powder diffraction data showed manganese in oxide films in all cases studied. The films obtained using compositions with vanadium oxide contain vanadium. There were, however, no traces of lead [9].

The IR spectra of the samples show several minima. According to [10], absorption bands at $420-440 \mathrm{~cm}^{-1}$ and $670 \mathrm{~cm}^{-1}$ correspond to Ga-O. The same bands appeared when the samples were oxidized without chemostimulators, which means that gallium oxide appears. The absorption band at $900 \mathrm{~cm}^{-1}$ usually corresponds to As-O, while the absorption band of $850 \mathrm{~cm}^{-1}$ corresponds to $\mathrm{Pb}-\mathrm{O}$. The second absorption band corresponding to As-O is $480 \mathrm{~cm}^{-1}$ and is similar to the second absorption band corresponding to $\mathrm{V}$-O. As the X-ray powder diffraction showed vanadium in oxide films, it is highly possible that the frequency corresponds both to As-O and $\mathrm{V}-\mathrm{O}$. The minimum absorption at $840 \mathrm{~cm}^{-1}$ corresponds to the fluctuations of Mn-O. Of particular interest are the absorption bands of $540 \mathrm{~cm}^{-1}$, which can be explained by the substrate's GaAs bond.

Our experiment, has thus demonstrated, that according to the X-ray powder diffraction and IR spectroscopic data, the chemostimulators become part of the oxide film grown on the GaAs surface. Moreover, the oxidized substrate elements are also present in the film (which is particularly important for arsenic).

Spatial separation of the chemostimulators [3-5] can be used to determine the localization of their interactions resulting in deviations from additivity (Fig.2). Figures 3 and 4 illustrate effects of $\mathrm{MnO}_{2}$ interacting with $\mathrm{PbO}$ and $\mathrm{V}_{2} \mathrm{O}_{5}$ in mixures and spatially separated (for oxide film thickness and relative integrated thickness respectively). Clearly, the overall effect of the chemostimulators in the thermal oxidation of GaAs is nonlinear for separate 
evaporation techniques. The nonlinearity is more pronounced in the separate evaporation experiments than in the mixture evaporation experiments.

Since the nonlinear effects arise from both solid- and gas-phase reactions in the case of mixture evaporation and only from gas-phase reactions in the case of separate evaporation, it is possible to separate the effective contribution from the solid-phase reactions to the overall effect.

At $530^{\circ} \mathrm{C}$ the nonlinear effects in the mixture evaporation and separate evaporation experiments are of the same sign and the corresponding relative integrated thicknesses are similar (Fig. 3, 4). Consequently, the contribution from the solid-phase reactions between the chemostimulators is of small positive value, and the negative overall deviation from additivity is due to the interaction between the oxides in the gas phase.

At $560^{\circ} \mathrm{C}$ the nonlinear effects in the mixture evaporation and separate evaporation experiments for both chemostimulator systems differ greatly both in magnitude and in the way they vary with composition.

The contribution from the solid-phase interaction is again positive throughout the chemostimulator composition range, but is larger. The fact that the contribution from the solid-phase interactions increases markedly with increasing temperature suggests that these interactions are chemical in nature. This inference is supported by X-ray powder diffraction data (which indicate the formation of $\mathrm{Mn}_{2} \mathrm{O}_{3}, \mathrm{Mn}_{3} \mathrm{O}_{4}$; and conversions $\mathrm{PbO} \rightarrow \mathrm{Pb}_{3} \mathrm{O}_{4} \rightarrow \mathrm{PbO}_{2}$ ).

The contribution from the gas-phase interaction between the chemostimulators increases negatively with increasing temperature and exceeds the positive contribution from the solid-phase interaction. As a result, the relative integrated thickness is negative and varies nonlinearly with the composition of the chemostimulator system.

The composition of the vapor over $\mathrm{PbO}+\mathrm{MnO}_{2}$ mixtures in the composition range from $20 \% \mathrm{PbO}+80 \% \mathrm{MnO}_{2}$ to $80 \% \mathrm{PbO}+20 \% \mathrm{MnO}_{2}$ was studied using high-temperature mass spectrometry (MS-1301) [11]. The mass spectra of the vapor over the samples from 920 to $980 \mathrm{~K}$ showed $\mathrm{Pb}^{+}, \mathrm{PbO}^{+}, \mathrm{Pb}_{2} \mathrm{O}_{2}{ }^{+}$and $\mathrm{Pb}_{4} \mathrm{O}_{4}{ }^{+}$ion peaks, indicating the presence of lead atoms and $\mathrm{PbO}, \mathrm{Pb}_{2} \mathrm{O}_{2}$ and $\mathrm{Pb}_{4} \mathrm{O}_{4}$ molecules in the vapor phase. The spectra do not indicate the presence of mixed molecular ions, such as $\mathrm{PbMnO}_{2}{ }^{+}, \mathrm{PbMnO}_{3}{ }^{+}, \mathrm{PbMnO}_{4}{ }^{+}$; therefore, there is no interaction between lead and manganese oxides in the condensed or gas phase. The most important result of the mass spectrometric study is that the relative lead atom concentration in the gas phase is higher for the mixtures used in the experiment than for pure $\mathrm{PbO}$. The $\mathrm{Pb} / \mathrm{PbO}$ ratio changes from 1.67 and 0.84 for $\mathrm{PbO}$-rich compositions to 0.80 and 0.73 for $\mathrm{MnO}_{2}$-rich compositions. The vapor over the mixtures contains all molecular species typical of the evaporation of pure $\mathrm{PbO}$; however, the $\mathrm{Pb} / \mathrm{PbO}$ partial pressure ratio indicates the domination of lead atoms. The $\mathrm{Pb}$ atom concentration in the gas phase is approximately twice higher in the evaporation of a $\mathrm{PbO}+\mathrm{MnO}_{2}$ mixture than in the evaporation of pure $\mathrm{PbO}$ [12]. In the presence of $\mathrm{MnO}_{2}$, the vapor contains polymerized lead oxide species; nevertheless, $\mathrm{PbO}$ definitely tends to decompose. It is due to this process that the oxide compositions show a lower chemostimulating activity in GaAs oxidation than pure $\mathrm{PbO}$ or $\mathrm{MnO}_{2}$ and, accordingly, a negative nonlinear effect is observed in the coaction of $\mathrm{PbO}$ and $\mathrm{MnO}_{2}$.

According to electron probe X-ray microanalysis (EPXMA) [13] (Table. 2, 3) data for $(\mathrm{PbO})_{0,8}\left(\mathrm{MnO}_{2}\right)_{0,2}$ compositions, the $\mathrm{Mn}: \mathrm{Pb}$ ratio of the film in the mixture, evaporation is $0.21(0.089 \%: 0.425 \%)$, while in a separate evaporation experiment, the ratio is 0.66 , i.e. the manganese, content of the film is about 3 times higher. For the manganese dioxide-rich composition $(\mathrm{PbO})_{0,2}\left(\mathrm{MnO}_{2}\right)_{0,8}$, the $\mathrm{Mn}$ : $\mathrm{Pb}$ ratio in the film is 0.42 for the mixture evaporation experiment and 0.84 for the separate evaporation experiment; that is, the separate 
$\mathrm{d}, \mathrm{nm}$

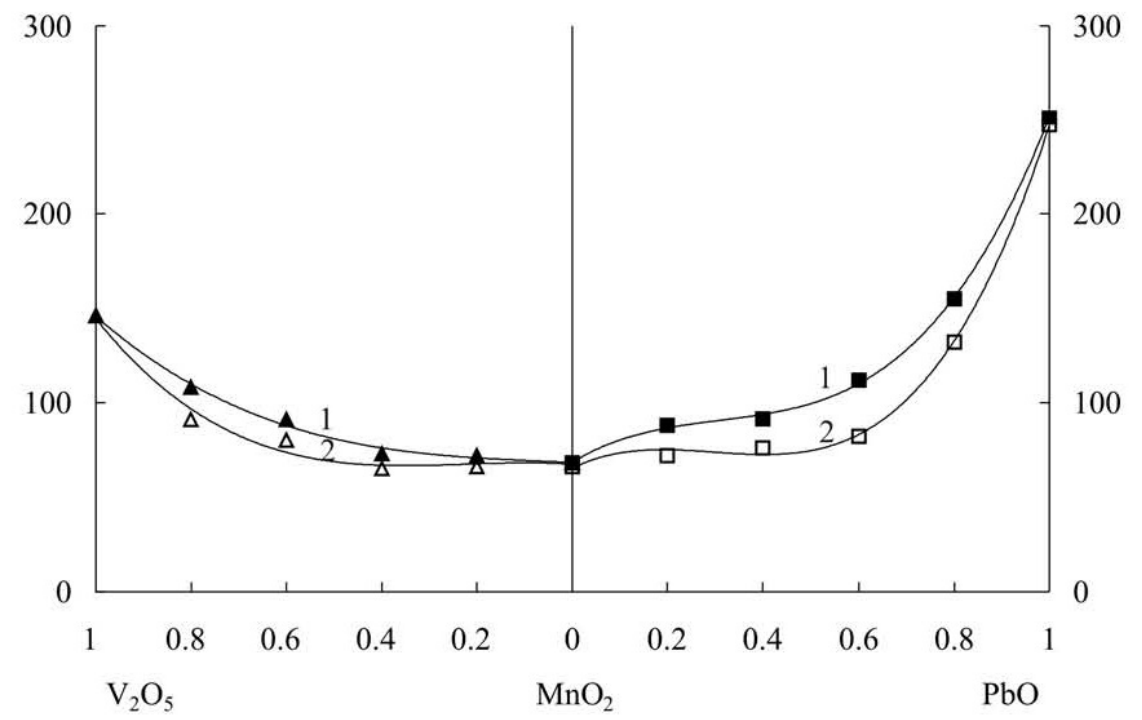

$\mathrm{d}, \mathrm{nm}$

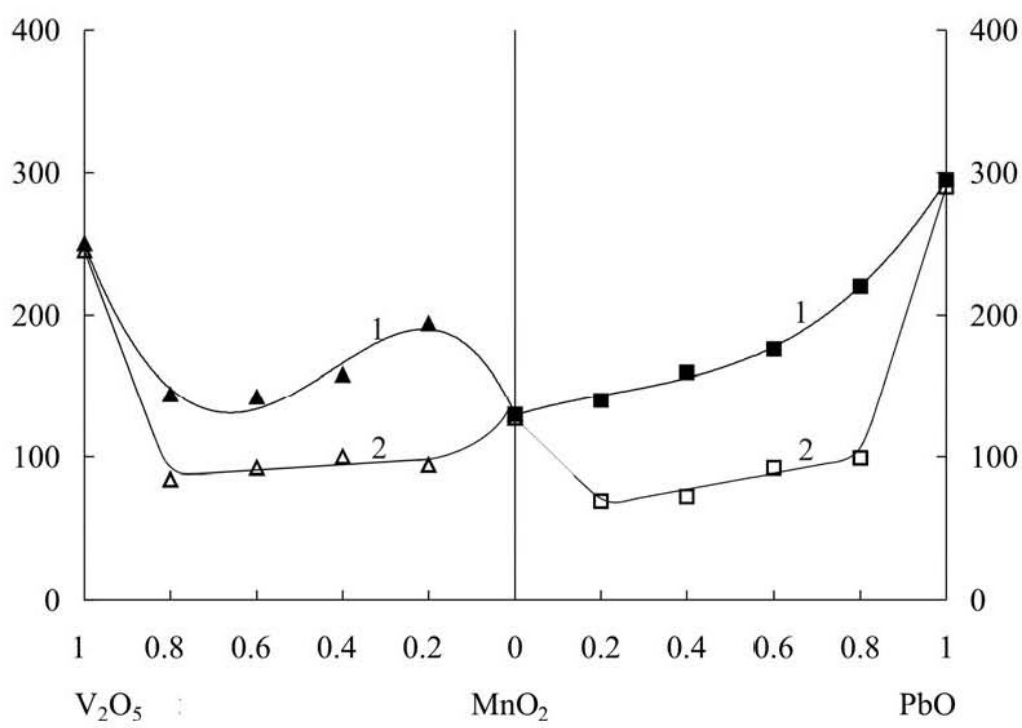

Fig. 3. The dependencies of the oxide films' thickness on the chemostimulator compositions $\mathrm{MnO}_{2}+\mathrm{PbO}$ and $\mathrm{MnO}_{2}+\mathrm{V}_{2} \mathrm{O}_{5}$ at $530^{\circ} \mathrm{C}$ (a) and $560^{\circ} \mathrm{C}$ (b), for 40 min.: 1 - mixture evaporation experiment; 2 - separate evaporation experiment

evaporation of the chemostimulators increases the manganese content of the film by a factor of 2 .

For the chemostimulator with $(\mathrm{PbO})_{0,8}\left(\mathrm{MnO}_{2}\right)_{0,2}$ composition, the ratio $\mathrm{Mn}_{\text {mixture }}$ / $\mathrm{Mn}_{\text {separate }}$ is about $2(0.089 / 0.046)$, i.e. in the case of separate evaporation, the manganese content of the film is about 2 times lower, while the lead content of the film is more than 6 times lower $-\mathrm{Pb}_{\text {mixture }} / \mathrm{Pb}_{\text {separate }}=0.425 / 0.068=6.25$. A similar pattern was observed for the $(\mathrm{PbO})_{0,2}\left(\mathrm{MnO}_{2}\right)_{0,8}$ composition: the manganese content ratio $\mathrm{Mn}_{\text {mixture }} / \mathrm{Mn}_{\text {separate }}$ was $2.6(0.136 / 0.052)$, and the lead content ratio $\mathrm{Pb}_{\text {mixture }} / \mathrm{Pb}_{\text {separate }}$ was $5.2(0.324 / 0.062)$. 

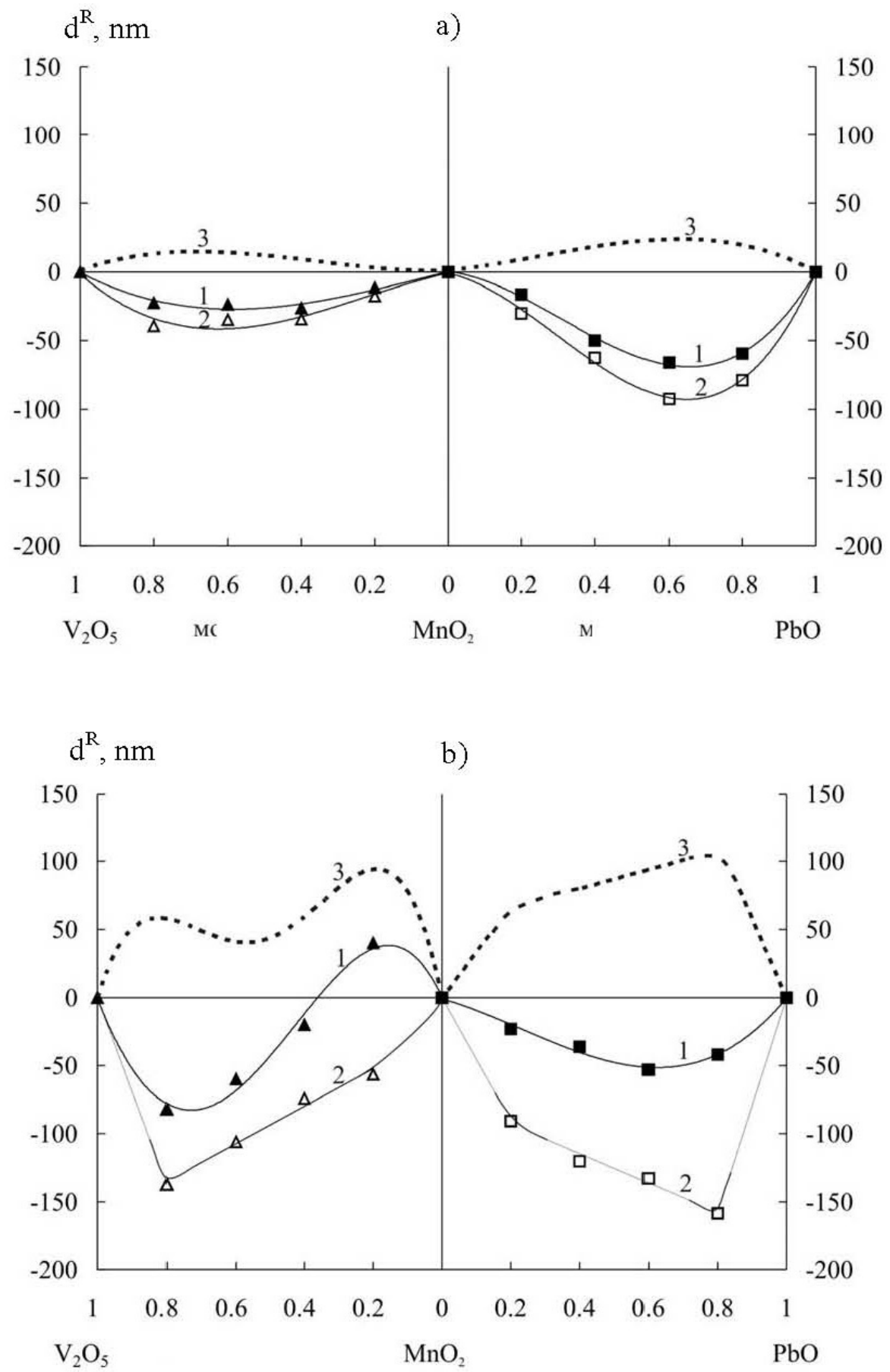

FIG. 4. The dependencies of the relative integrated films thickness on the chemostimulator compositions $\mathrm{MnO}_{2}+\mathrm{PbO}$ and $\mathrm{MnO}_{2}+\mathrm{V}_{2} \mathrm{O}_{5}$ at $530^{\circ} \mathrm{C}$ (a) and $560^{\circ} \mathrm{C}$ (b), for 40 min.: 1 - mixture evaporation experiment; 2 - separate evaporations experiment; 3 - calculated contribution from the gas-phase interaction between the chemostimulators 
TABLE 2. EPXMA data for the samples obtained by the thermal oxidation of $\mathrm{GaAs}$ at $560^{\circ} \mathrm{C}$ for $40 \mathrm{~min}$ in the presence of $\mathrm{MnO}_{2}+\mathrm{PbO}$ compositions introduced by the mixture evaporation and separate evaporation techniques

\begin{tabular}{|c|c|c|c|c|}
\hline \multicolumn{5}{|c|}{ Elemental composition of the films, at \% } \\
\hline $\mathrm{Ga}$ & As & $\mathrm{Mn}$ & $\mathrm{Pb}$ & $\mathrm{O}$ \\
\hline \multicolumn{5}{|c|}{ Separate evaporation } \\
\hline \multicolumn{5}{|c|}{20 mole $\% \mathrm{MnO}_{2}+80$ mole $\% \mathrm{PbO}$} \\
\hline 29.439 & 4.383 & 0.046 & 0.068 & 66.028 \\
\hline \multicolumn{5}{|c|}{ Activating composition $-\mathrm{Mn}: \mathrm{Pb}=1: 4$} \\
\hline \multicolumn{5}{|c|}{ Film $-\mathrm{Mn}: \mathrm{Pb}=1: 1.47$} \\
\hline \multicolumn{5}{|c|}{80 mole $\% \mathrm{MnO}_{2}+20$ mole $\% \mathrm{PbO}$} \\
\hline 33.570 & 4.882 & 0.052 & 0.062 & 61.415 \\
\hline \multicolumn{5}{|c|}{ Activating composition - $\mathrm{Mn}: \mathrm{Pb}=4: 1$} \\
\hline \multicolumn{5}{|c|}{ Film $-\mathrm{Mn}: \mathrm{Pb}=1: 1.35$} \\
\hline \multicolumn{5}{|c|}{ Mixture evaporation } \\
\hline \multicolumn{5}{|c|}{20 mole $\% \mathrm{MnO}_{2}+80$ mole $\% \mathrm{PbO}$} \\
\hline 28.548 & 3.421 & 0.089 & 0.425 & 67.517 \\
\hline \multicolumn{5}{|c|}{ Activating composition $-\mathrm{Mn}: \mathrm{Pb}=1: 4$} \\
\hline \multicolumn{5}{|c|}{ Film $-\mathrm{Mn}: \mathrm{Pb}=1: 4$} \\
\hline \multicolumn{5}{|c|}{80 mole $\% \mathrm{MnO}_{2}+20$ mole $\% \mathrm{PbO}$} \\
\hline 31.124 & 4.156 & 0.136 & 0.324 & 64.260 \\
\hline \multicolumn{5}{|c|}{ Activating composition $-\mathrm{Mn}: \mathrm{Pb}=4: 1$} \\
\hline & Film & $\mathrm{a}: \mathrm{Pb}$ & 2.4 & \\
\hline
\end{tabular}

Thus, the apparently higher manganese content of the films obtained by the separate evaporation of the chemostimulators is due to the decreased percentage of lead, which is a more effective chemical stimulator. It is this circumstance that enhances the negative nonlinear effect in the case of the separate evaporation of the chemostimulators.

This marked decrease in the chemical stimulation activity of lead oxide is caused by the enhancement of dissociation processes in the gas phase, as in the case of p-elementcontaining mixtures [2]. Due to these processes, the concentration of lead atoms, which are not chemical stimulators, is up to 2 times higher in the vapor over $\mathrm{PbO}+\mathrm{MnO}_{2}$ than in the vapor over pure $\mathrm{PbO}[12]$. Although chemically stimulated oxidation is carried out under flowing oxygen, which can oxidize lead atoms, the efficiency of the oxygen transit transfer to the substrate components is much lower in this case. The nature of the precursor is significant here: the lead atom resulting from a transit transfer event is in an active, excited state, unlike the lead atoms present in the gas phase. If solid-phase interactions take place ( $\mathrm{PbO}$ oxidation by manganese dioxide into higher lead oxides), the dissociation processes in the gas phase will be suppressed to some extent, particularly in the case of manganese dioxide-rich compositions. Thus, the solid-phase interactions in the $\mathrm{PbO}+\mathrm{MnO}_{2}$ mixtures somewhat hamper the dissociation processes in the gas phase, thereby making a positive contribution to the observed nonlinear effect. The fact that this contribution increases with increasing temperature is obviously explained by the rate enhancement of redox addition reactions in the solid phase. 
TABLE 3. EPXMA data for the samples obtained by the thermal oxidation of $\mathrm{GaAs}$ at $560^{\circ} \mathrm{C}$ for $40 \mathrm{~min}$ in the presence of $\mathrm{MnO}_{2}+\mathrm{V}_{2} \mathrm{O}_{5}$ compositions introduced by the mixture evaporation and separate evaporation techniques

\begin{tabular}{|c|c|c|c|c|}
\hline \multicolumn{5}{|c|}{ Elemental composition of the films, at \% } \\
\hline $\mathrm{Ga}$ & As & Mn & $\mathrm{V}$ & $\mathrm{O}$ \\
\hline \multicolumn{5}{|c|}{ Separate evaporation } \\
\hline \multicolumn{5}{|c|}{20 mole $\% \mathrm{MnO}_{2}+80$ mole $\% \mathrm{~V}_{2} \mathrm{O}_{5}$} \\
\hline 30.524 & 4.821 & 0.052 & 0.255 & 64.348 \\
\hline \multicolumn{5}{|c|}{ Activating composition $-\mathrm{Mn}: \mathrm{V}=1: 4$} \\
\hline \multicolumn{5}{|c|}{ Film $-\mathrm{Mn}: \mathrm{V}=1: 5$} \\
\hline \multicolumn{5}{|c|}{80 mole $\% \mathrm{MnO}_{2}+20$ mole $\% \mathrm{~V}_{2} \mathrm{O}_{5}$} \\
\hline 30.718 & 4.654 & 0.301 & 0.076 & 64.248 \\
\hline \multicolumn{5}{|c|}{ Activating composition - Mn : V = 4: 1} \\
\hline \multicolumn{5}{|c|}{ Film $-\mathrm{Mn}: \mathrm{V}=4: 1$} \\
\hline \multicolumn{5}{|c|}{ Mixture evaporation } \\
\hline \multicolumn{5}{|c|}{20 mole $\% \mathrm{MnO}_{2}+80$ mole $\% \mathrm{~V}_{2} \mathrm{O}_{5}$} \\
\hline 29.486 & 3.583 & 0.164 & 0.648 & 66.119 \\
\hline \multicolumn{5}{|c|}{ Activating composition $-\mathrm{Mn}: \mathrm{V}=1: 4$} \\
\hline \multicolumn{5}{|c|}{ Film $-1: 4$} \\
\hline \multicolumn{5}{|c|}{80 mole $\% \mathrm{MnO}_{2}+20$ mole $\% \mathrm{~V}_{2} \mathrm{O}_{5}$} \\
\hline 28.843 & 3.871 & 0.643 & 0.254 & 66.389 \\
\hline \multicolumn{5}{|c|}{ Activating composition $-\mathrm{Mn}: \mathrm{V}=4: 1$} \\
\hline & Film & $\mathrm{V}=$ & & \\
\hline
\end{tabular}

For a given activator composition, the films obtained using the mixture evaporation and separate evaporation techniques are comparable in terms of their $\mathrm{Mn}$ : V ratio (Table 3). For example, for $\left(\mathrm{MnO}_{2}\right)_{0,2}\left(\mathrm{~V}_{2} \mathrm{O}_{5}\right)_{0,8}, \mathrm{Mn}: \mathrm{V}=0.052: 0.255=1: 5$ for the separate evaporation technique, and $\mathrm{Mn}: \mathrm{V}=0.164: 0.648=1: 4$ for the mixture evaporation technique; that is, for an activating mixture containing excess vanadium oxide, the manganese content of the film and, therefore, that of the gas phase are somewhat higher for mixture evaporation than for separate evaporation. By contrast, for $\left(\mathrm{MnO}_{2}\right)_{0,8}\left(\mathrm{~V}_{2} \mathrm{O}_{5}\right)_{0,2}, \mathrm{Mn}: \mathrm{V}=4: 1$ for separate evaporation, and $\mathrm{Mn}: \mathrm{V}=2.6: 1$ for mixture evaporation; that is, the manganese content of the film is lower for mixture evaporation than for separate evaporation. At the same time, the relative amounts of the elements in the film change in the same way in passing from one evaporation technique to the other: both manganese and vanadium contents are 2-3 times higher for mixture evaporation than for separate evaporation. For the $\left(\mathrm{MnO}_{2}\right)_{0,2}\left(\mathrm{~V}_{2} \mathrm{O}_{5}\right)_{0,8}$ composition the $\mathrm{Mn}_{\text {mixture }} / \mathrm{Mn}_{\text {separate }}$ ratio is $3.15(0.164 / 0.052)$, and the $\mathrm{V}_{\text {mixture }} / \mathrm{V}_{\text {separate }}$ ratio is $2.54(0.648 / 0.255)$. For the $\left(\mathrm{MnO}_{2}\right)_{0,8}\left(\mathrm{~V}_{2} \mathrm{O}_{5}\right)_{0,2}$ composition, the $\mathrm{Mn}_{\text {mixture }} / \mathrm{Mn}_{\text {separate }}$ ratio is $2.14(0.643 / 0.301)$, and the $\mathrm{V}_{\text {mixture }} / \mathrm{V}_{\text {separate }}$ ratio is $3.34(0.254 / 0.076)$. Thus, due to the solid-phase interactions, the manganese and vanadium contents of the film and, therefore, the manganese and vanadium oxide contents of the vapor are higher in the case of mixture evaporation (according to IR spectroscopic data, the chemostimulators in the film are in their oxidized states); i.e., the dissociation processes in oxide evaporation are somewhat hampered by the solid-phase interactions. 


\section{Conclusions}

The observed nonlinear effects appearing during GaAs thermal oxidation under the coaction of manganese (IV) oxide - lead (II) oxide and manganese (IV) oxide - vanadium(V) oxide compositions can be attributed to their interaction in the initial powder mixture under the conditions corresponding to the process studied. These effects result in differences in their oxide film contents grown on GaAs surfaces and hence, differences in their chemostimulation capacities. The solid-phase interactions between the chemostimulators (during the evaporation of their mixtures) extend the lifetime of molecular oxide species in the vapor, giving rise to a positive thermal oxidation effect. The gas-phase interactions between the chemostimulators are mainly dissociative. They reduce somewhat the chemostimulating effect and make a negative contribution to the nonlinear effects.

\section{Acknowledgements}

The reported study was supported by he Ministry of Education and Science of the Russian Federation as a project part of the State Task for higher education institutions in the sphere of scientific research for years 2014-2016 (project N 225), and funded by the Russian Foundation for Basic Research (grant N 13-03-00705-a).

\section{References}

[1] Mittova I.Ya., Pshestanchik V.R., Kostryukov V.F. Thermal Oxidation of Gallium Arsenide in oxygen: combined effect of Antimony and Bismuth oxides. Russian Journal of Inorganic Chemistry, 1997, 42(2), P. $182-187$.

[2] Mittova I.Ya., Pshestanchik V.R., Kostryukov V.F. Alternating Alternating nonlinearity of the joint activating effect of binary mixtures of p-element oxides on the chemically activated thermal GaAs oxidation. Doklady Chemistry, 2001, 378(4-6), P. 165-167.

[3] Mittova I.Ya., Kostryukov V.F. GaAs Thermal oxidation activated by the coaction of p-block oxides. Nanosystems: physics, chemistry, mathematics, 2014, 5(3), P. 417-426.

[4] Mittova I.Ya., Pshestanchik V.R., Kostryukov V.F., Donkareva I.A. Spatial Localization of Interactions between Activating Additives during Chemostimulated Thermal Oxidation of GaAs. Doklady Chemistry, 2002, 386(4-6), P. 258-260.

[5] Mittova I.Ya., Pshestanchik V.R., Kostryukov V.F., Donkareva I.A. Mutual Effect of Activators on Chemostimulated GaAs Thermal Oxidation with Spatially Separated Coupling Stages. Russian Journal of Inorganic Chemistry, 2003, 48(4), P. 480-483.

[6] Mittova I.Ya., Pshestanchik V.R. The chemistry of processes which create dielectric layers with functional group substituents on semiconductors by impurity thermo-oxidation. Russian Chemical Reviews, 1991, 60(9), P. 967-980.

[7] Sladkopevtcev B.V., Tretyakov N.N., Dontsov A.I., Tomina E.V., Mittova I.Ya. Effect of oxide composition $\left(\mathrm{V}_{2} \mathrm{O}_{5}+\mathrm{Al}_{2} \mathrm{O}_{3}\right)$ via gas phase on the thermal oxidation of InP. Nanosystems: physics, chemistry, mathematics, 2013, 4(2), P. 260-268.

[8] Diffraction Data. Catalog. International centre for diffraction data.

[9] Hufner S. Photoelectron Spectroscopy. Principles and Applications. Heidelberg, Springer Verlag, 1995, 515 p.

[10] Nakamoto K. Infrared and Raman Spectra of Inorganic and Coordination Compounds. World, Moscow, 1991, $441 \mathrm{p}$.

[11] Balicheva T.G., et al. Physical methods of inorganic substances. Academia, Moscow, 2006,442 p.

[12] Kazenas E.K., Tsvetkov Yu.V. Evaporation of oxides. Science, Moscow, 1997, 543 p.

[13] Goldstein J.I., Newbury D.E., Echlin P. Scanning Electron Microscopy and X-Ray Microanalysis, 1992, 829 p. 